\title{
An Ethnography of Two Teachers' Antiracist and Critical Multicultural Practices
}

\author{
Dolana Mogadime \\ Brock University
}

\begin{abstract}
Educational theorists concerned with antiracist and critical multicultural practices have identified the need for teachers to begin changing the processes of social exclusion which children of colour experience in the school system. An ethnographic study of critical educators teaching practices is provided as a useful directive. The study examines how two critical educators respond to the diversity represented in their school by incorporating antiracist and critical multicultural approaches in their teaching practice. Of interest in relation to Julia Neuman's practice is the question: How do white teachers negotiate their 'whiteness' in relation to the diversity in student population? In the case of Sita Ramana a South Asian teacher, the study considers how cultural and linguistic congruence with her students engages their interests in culturally response reading programs that involve dual language books as well as parent - student active participation in heritage language programs.
\end{abstract}

Keywords: Ethnography; Ontario elementary schools; antiracism; critical multicultural education; critical educators; dual language books

Dolana Mogadime, Ph.D., is an Associate Professor in the Faculty of Education at Brock University in St. Catharines, Ontario, Canada. Currently, she teaches both graduate and undergraduate courses in the 'Social Cultural Contexts of Education' field of study. Her research has been published in international journals and anthologies related to diversity, Black studies, feminism and Black feminism.

Email: dmogadime@brocku.ca

Note: The names of all persons, schools and school districts have been changed in order to guarantee their anonymity.

Brock Education, Vol. 21, No. 1, Fall 2011, 33-52 


\section{An Analysis of Two Critical Educators' Practice: Research Concerns and Questions}

In this paper, I have provided a detailed analysis of the practices of two critical educators. I examined how they responded to the diversity represented in their school by incorporating antiracist and critical multicultural approaches in their teaching practice. Educational theorists concerned with antiracist and critical multicultural practices have identified the need for teachers to begin changing the processes of social exclusion which children of colour experience in the school system (Dei, 1997). They suggest that teachers should begin with interrogating how their own racial and social backgrounds influence and shape practice (Sleeter, 1994).

In this study, I was specifically interested in analyzing the "race cognizant" (Frankenberg, 1993) work of one white educator who was politically committed toward transforming the processes of social exclusion which culturally diverse students experience through the curriculum as a racialized text. I show how an antiracist approach in teaching, arises out a teacher's critique of the normalization of whiteness in mandated curriculum. With particular attention to language arts and social studies, I examine not only how an antiracist white teacher takes up critical multicultural texts, but also how she engages her students in critiquing historically constructed white dominance in and through critical dialogue in the classroom.

In taking seriously the notion that teachers' race and cultural background provides critical lenses through which to view teaching, I also make inquiries about how a teacher of colour views her racial and cultural background as having an influence on classroom practice. I do so, by investigating the following questions: How does an educator who shares an insider's knowledge of the community's children use this knowledge to reconceptualize teaching practice? Further how do these practices engage the interests of students whose linguistic and cultural backgrounds are congruent with their teacher's? These questions allow for the inclusion of culturally diverse teachers' special knowledge and sensibilities which have been subjugated in Canadian educational discourse.

\section{Research Site, Methods and Procedures}

Two women teachers (located in the same school) participated in an ethnographic study of their classrooms. When the research took place, between March 1999 and August 2000, Elmwood Elementary School had a school enrollment of 700 students. I selected this school because it served students from communities that represent the cultural diversity in Canadian society today (Mogadime, 2003). The racial makeup of the staff had changed a few years prior to the commencement of the study because of the school leadership's support of equity in employment. About half of the staff of 50 teachers were 'racial minorities.' Because I was interested in the contribution of both 'racial minority teachers' and white teachers to the school system, this school was an ideal place to carry out the research.

I used a multiple data-collection procedure referred to as triangulation (Glesne \& Peshkin, 1992, p. 24) which has informed the work of other classroom ethnographies (Henry, 1998; Weiler, 1988). The data-gathering techniques included naturalistic observations in the classroom (Woods,

Brock Education, 21(1), 33-52 
1986) and in-depth semi-structured and life history interviews (Geiger, 1986; Heron, 1985). I used research procedures to examine connections between personal beliefs and professional practice in the classroom. The observations I conducted in the classroom produced questions about the nature of teacher's pedagogy, and political beliefs (in relation to transformative practice), that I further verified, explained or clarified through the interviews. Thus I have provided accounts of the observed classroom practice of the two teachers, Julia Neuman (of a Euro-Canadian English speaking background) and Sita Ramana (of a South Asian Tamil speaking background). I visited these two teachers in their classrooms once each week over a period of two school terms, and an intensified period of one school term (with visits occurring three or four times a week). I focused on observing and recording literature based approaches to teaching integrative language arts and social studies. This involved literacy events such as read-aloud time, response journals, student-led literature discussions, and collaborative story writing. During these events I audio recorded, observed, and documented the conversations teachers and students had with multicultural texts, the instructional techniques that supported critical conversations such as problem-posing and the multiple ways in which students participated in responding to texts through journal writing, reader's theatre, and story drama. I also collected student work (such as response journals) and conducted student interviews to use as additional data sources. My main purpose was to both observe and document how teachers negotiate with mandated curriculum and find ways to implement transformative practice through the use of critical multicultural texts and critical literacy practice in social studies and language arts.

\section{Theoretical Framework: Constructing a Political Subject Position of the Critical Educator and Student}

Critical theorists, antiracist theorists, and critical multiculturalists have in common the interest in working toward social justice in education (Lund, 2003) which becomes apparent in their common theorization around the political subject position of the critical educator and student. For example, critical theorists explain the role an educator plays as 'transformative intellectual' as one that involves performing a particular social and political function that includes inserting schooling in a democratic public sphere (McLaren, 1994, p. 237). According to McLaren, this political sphere recognizes that schooling represents both "the struggle for meaning and a struggle over power relations." The educator who is a transformative intellectual is positioned with a concern for the "struggles of the disadvantaged and oppressed" (p. 238). Antiracist theory envisions antiracist educators as summoning this same critical subject position in that they "critique the supposed neutrality of institutions such as schools" (Sleeter \& Delgado Bernal, 2004, p. 251) and challenge systematic racism experienced by the disadvantaged and oppressed as McLaren has described. According to Sleeter and Delgado Bernal (2004), antiracist education and theory, which begins with an analysis of historic and contemporary imperialism and racism, "examines how a racist system is maintained, roles of individuals in maintaining it, and how racism can be challenged both collectively and individually" (p. 250).

Sleeter's and Delgado Bernal's discussion of the language of critic demonstrates intersections

Brock Education, 21(1), 33-52 
between antiracist theory and critical pedagogy. They explain that, "Antiracist teaching entails helping students identify manifestations of racism, learn how racism works, and learn to interrupt it. Anti-racism gives tools not only to talk about racism but also to do something about it" (pp. 250251). Likewise McLaren (1994) describes the role of the transformative intellectual as one that includes "treating students as critical agents [who] question how knowledge is produced and distributed" (p. 238). The transformative intellectual “...utilize[s] dialogue, and make[s] knowledge meaningful, critical and ultimately emancipatory" (p. 238). Critical multiculturalists (Banks, 1991; May, 1999) who, summon this same critical subject position in the student insist that student empowerment can only be achieved when students not only have "knowledge of their social, political and economic worlds," but also when they "have the critical thinking skills" with which to "influence their environments (Banks, 1991, p. 125). According to critical theorists, critical multiculturalists, and antiracist theorists, both teacher and student are positioned as critical agents in the struggle against the hegemony of school knowledge which reproduces the curriculum as neutral.

One of the central aims of the classroom ethnography in Julia Neuman's class and Sita Ramana's class was to document how teacher's political beliefs in integrating students' cultural and linguistic backgrounds with school knowledge counteracts the notion of the curriculum as neutral. The culturally responsive pedagogy that the two critical educators enact (Julia Neuman in the next section followed by Sita Ramana), contributes towards the kind of emanipatory vision that supports culturally diverse students in developing critical voice so that they may ultimately participate in the kind of social change that will "help create a more just society and world" (Banks, 1991, p. 125).

\section{Julia Neuman's Grade-3 Classroom: Teaching From Multiple Perspectives}

I was interested in the political moments in which teachers' beliefs in transformative/ emancipatory practices (Mclaren, 1994) were enacted. This would include the taking up of critical multicultural texts, and critical dialogue/talk or conversations through critical multicultural literacy practices (Banks, 1991; Leland \& Harste, 1999; Powell, 1999). Critical multiculturalist and antiracist educators have discussed the value of teaching from multiple social perspectives (Banks, 1991, 1997, 2001; Dei, 1996; Powell, 1999). They have argued that engaging the interests of students from multiracial backgrounds involves transforming the curriculum toward legitimizing formally silenced or marginalized histories and social realities.

I entered Julia Neuman's classroom to record those events of her classroom that were tied to two areas of the curriculum that support literacy development (language arts and social studies). Figures 1 and 2 outline the multiple perspectives that informed Julia Neuman's re-visioning of the Grade-3 social studies curriculum and the literacy events that she planned to support student engagement and language development. Using critical multicultural texts that included stories of Chinese immigration, and facilitated a dialogue about African American and Europeans immigration to Canada, Julia reworked the Eurocentric focus of the Ontario mandated social studies (pioneer) curriculum to reflect the cultural identities of the students in her class. Figures 1 and 2 provide an illustration of the literature-based program which Julia implemented.

Brock Education, 21(1), 33-52 
Figure 1: Multicultural children's literature selected by critical educator Julia Neuman

Book selection for read aloud time in an integrated social studies and language arts curriculum

1. First Nations Peoples:

"This Land Is My Land"

(Author: George Littlechild).

2. First Nations Peoples:

"Houses of Adobe" and

"Native Dwellings: The Southwest"

(Author: Bonnie Shemie).

3. African American Pioneers:

"Wagon Wheels"

(Author: Barbara Brenner).

4. African American Pioneers:

"I Have Heard of a Land"

(Author: Joyce Carol Tomas).

5. Early Chinese Immigration to Canada.

"Ghost Train" and "Tales from Gold

Mountain"

(Author: Paul Yee).

6. European Pioneers. "Pettranella"

(Author: Betty Waterton).

Brock Education, 21(1), 33-52 
Figure 2: Literacy Events

1. D.E.A.R. (Drop Everything And Read)Time:

Students self-select children's books for independent reading (books read during read aloud were also available for students, some chose to read these during D.E.A.R. time).

2. Read Aloud:

Teacher selected books based on a thematic study (in this case books were selected which reflected multiple perspectives on the pioneer theme -- see reading list cited in Figure 1).

3. Reader Response Involved A Variety Of Sign Systems As Well As A Dance Between Aesthetic and Efferent Stances:

Oral: Critical Conversations about issues of social justice

A. Written: Journal Writing which invites taking critical positions in responding to texts.

B. Aesthetic/Efferent: Story Drama, Reader's Theatre and Role Playing as a means to critique the social worlds represented in texts invited children to imagine a more socially just society.

C. Aesthetic responses: Building First Nations' dwellings

D. Oral and Written: Collaborative Story Writing

4. Mini Lessons

Conventions in Writing (e.g. how to write a paragraph)

\section{Text, talk, and pedagogy in Julia's Grade-3 Classroom}

Children's literature presents an opening for creating contexts for critical conversations in the classroom. I closely look at some of the classroom routines, curriculum and teaching, or the texts, talk and pedagogy which come out of these planned activities with the view to illustrate how research on best practice in literacy education augment critical multicultural literacy (see Figure 3 for a sample of the planned daily classroom schedule of literacy events). 
Figure 3: Julia's Class Schedule

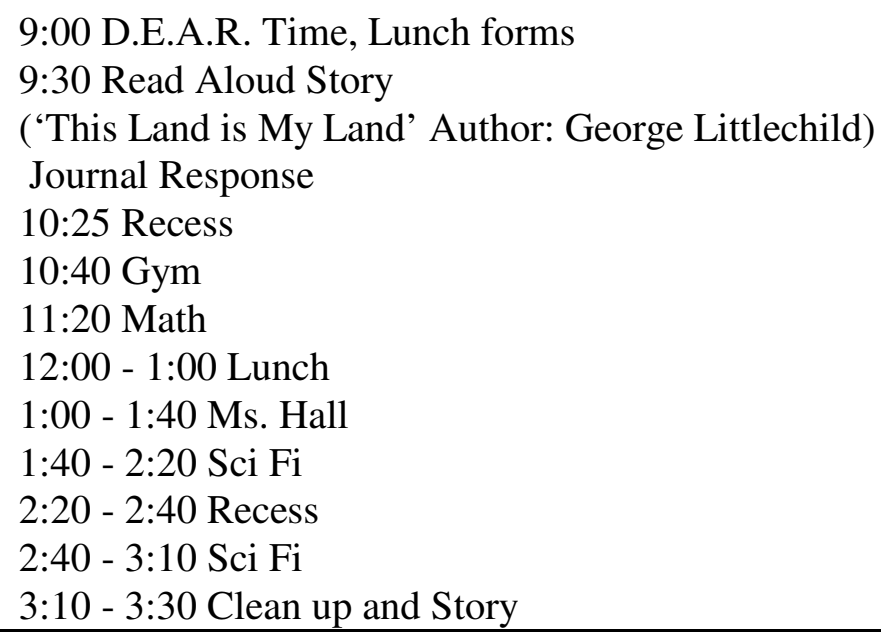

\section{An ecologically balanced literacy curriculum}

I observed Julia's critical multicultural literacy practice as it was enacted in an ecologically balanced manner which is suggested by Pearson and Raphael (1998). Pearson and Raphael call for a balance between convention and invention or the individual and cultural expectations - they argue that students need to be taught to become literate citizens who can both connect with past (or conventional knowledge) as well as have the capacity to deal with the uncertainty of the future (through their capacity for invention). Julia based the Holistic components of her literacy program on the fact that children engaged in a variety of activities which were student centered; such as self-selecting texts during Drop Everything and Read (D.E.A.R.) time, they read high quality trade books, for real purposes (e.g. to discuss their interpretations in literature circles) and for real audiences (e.g. to present in reader's theatre). Again these literacy events are described in Figure 1 and 2. Julia's schedule (Figure 3) also reflects a language-based approach to teaching across the curriculum, in that, Julia typically plans extended blocks of time for reading, writing and responding to texts. Social studies is fully integrated with language arts.

Julia has well established routines that she has planned and worked hard at putting into place. These routines have thoughtfully evolved through the year with some trial and adjustment. Having a class that has a high ratio of English as a Second Language (ESL) students contributed to Julia's decision to devise routines in the class which involve repeated opportunities for language development. For instance, substantial blocks of time were committed to literacy. The average classroom morning schedule committed 9:00 - 10:25 (or to recess) to literacy. The morning began at 9:00 ritualistically with D.E.A.R. time in which children had a rich variety of books from which they would self-select texts according to their own interests. Different genres such as poetry, short stories,

Brock Education, 21(1), 33-52 
mysteries, and multicultural children's literature were within reach. D.E.A.R. time is followed by read aloud time, at which time Julia reads from a variety of books which are connected holistically across the language arts and social studies curriculum. After read aloud time the children are routinely given a 'reading response' journal assignment in which they are expected to record their reflections on the texts read loud. Julia typically conducts a mini lesson in which she outlines the expectations for the journal responses.

\section{Engaging students in critical literacy practice/ postcolonial texts and narrative drama}

Julia began implementing critical literacy practices in her classroom by presenting the social studies curriculum and the unit on Early Pioneers as a problem. Contrary to the Ontario curriculum document which presents the period of early settlement and pioneer life in a generic raceless style, Julia placed the voices of cultures that have been traditionally marginalized in history at the center of classroom texts and reading response literacy activities. These included not only the story of European pioneers but also Black pioneers as represented in Joyce Thomas's (1996) feminist book on Black women pioneers 'I Have Heard of a Land,' and Paul Yee's (1996a) representation of Chinese pioneers in 'Ghost Train,' as well as the inclusion of First Nations people who had traveled and settled throughout North America long before the advent of the British and French pioneers, as represented by George Littlechild's (1993) book 'This Land is My Land.' Julia asked her students to make intertextual connections and comparisons between these texts- further extending their knowledge of a multi-centric knowledge basis about the topic under investigation (Dei, 1996).

Julia selected books that supported critical conversations in the classroom and encouraged children to look at how systems of oppression have structured human relations historically. When the class looked at First Nations author and artist George Littlechild's postcolonial picture book "This Land is My Land" during read aloud time they were asked to; understand the author's point of view; understand how biography influences the act of writing; try and understand the subjectivity which the author brought to the work of writing the text; understand how an author positions readers; rethink the point of contact (and its aftermath) from the position of the 'other' or from that of First Nations' people.

As a First Nations author, George Littlechild's children's book provides context for discussions on European exploration and initial contact with North American First Nations people. Questions of colonization and the objectification of First Nations people during the period of colonization were raised as Julia invited students to become critically conscious of the relations of dominance and power that characterized this period in history.

The following vignette has been developed from (both audio recordings and) written observations during read aloud time. These data sources provide a powerful example of how postcolonial texts are used to invite critical conversations in the classroom: 


\section{Read Aloud and Response to George Littlechild's Postcolonial Text}

It is 2:30 p.m. Julia faces her students as she sits on her chair. Her students are seated comfortably crossed legged on the carpet in front her. These are familiar moments which fill the afternoons. Today Julia holds up the book titled "This Land Is My Land" so all can closely see the cover. Her vivacious demeanor and high level of energy reflects an intense interest in the book and the conversation which is about to be shared. Julia immediately opens up the conversation with a line of questioning which invites her students to participate in the conversation as question posers. Students seem to magnetically pick up on her enthusiasm and energy from the point of curiosity and desire to know more.

Julia asks: "Did Christopher Columbus actually discover North America?" She uses this question to go over the idea of historical accounts which tell only partial truths because they are based on inaccuracies. She raises the well known point that when Christopher Columbus arrived on the shore of North American he thought he had arrived in India and thus Aboriginals became known as 'Indians' which they weren't. By questioning inaccuracies and the representation of inaccuracies as historical truths Julia invites students to begin the process of dispelling popular cultural myths about 'discovery' and the representation of the 'heroic' role of Europeans in the 'discovery' of the Americas. Stimulating critical thinking she adds "If Christopher Columbus didn't discover North America, then why do so many stories tell tales that say that he did?" Julia's questions aspire to ignite interpretive thought among students which goes beneath surface impressions.

Julia responds to students opinions and impressions by acknowledging their ideas as possibilities which might have contributed to the traditional North American story of pioneer life, a story which actively silences the reality of a First Nations presence as it simultaneously magnifies the European explorer and settler experience in the 'new world.' Julia links these themes to the common impressions people have about the North American pioneering story which holds up the European view as the most legitimized and normalized view of history when she says, "That could be why when people start talking about pioneers they think that no one was here before...we always get the story from the European point of view....because he [Christopher Columbus] was this famous explorer..."

After the children have thought seriously about the possible reasons for historical omissions and mistruths and have come up with the notion that it might have been racism that contributed to these erasures, Julia turns the question of racism back to the class when she asks, "why do you think that [racism] happened?" Alison immediately answers, "maybe white people didn't like people of different colors." Nathan [a white child] interjects, "it wasn't everyone who liked slavery - some people helped others follow the Drinking Gourd." Nathan is using his prior reading 
of texts taken up previously in class to argue the point that there were white people who didn't subscribe to racism. As such Nathan summons an intertextual comparison between white racism in one context (during the time of slavery and the abolitionist movement) with white racism in relation to the treatment of Aboriginal people as he insists that not all whites should be cast in one role, or not all white people were racists.

Julia listens but doesn't interject, preferring children come to their own understanding about the questions which they have themselves put forward. These questions can be summarized as follows: Did racism contribute to inaccuracies in the telling of stories about the first contact? Were white people racist at the point of European contact with First Nations?

Before Julia had actually started reading Littlechild's text, she had already inspired the children to start thinking in alternative ways about the way history is told. Critical questions are being asked such as whose perspective is privileged in the story of explorers- in the story of the first contact between Europeans and First Nations and in the story of North America and Canadian Nation building or pioneer settlement. Through the author, George Littlechild, Julia introduces a perspective on the encounter which is often overlooked (that of the First Nations People).

Following the readings from Littlechild's book, Julia asked her students to respond to the text through journal writing. She evoked emotional aesthetic responses by asking her students to respond the question: How would you feel (thinking from opposite perspectives)? One student, Vi, wrote the following in her journal:

How Would You Feel?

Christopher Columbus discovered North America, but the Aboriginal people were first. If I were an Aboriginal, I would be very disappointed to see North America taken away from me (and the Aboriginal people). I think that Columbus just wanted all the fame and glory, and to be part of history so Christopher Columbus said that he discovered North America. If I were Columbus I would tell the government (and the people) that I was the first white man to discover America but that the Aboriginal people were there before me so even if I get all the credit I would share half the credit with the Aboriginal people.

(Vi, a Grade-3 student)

Although Vi's response articulates a personal, private emotive interpretation about the implications of the point of contact, Vi's thinking and writing also shifts to the public (efferent)

Brock Education, 21(1), 33-52 
aspects by addressing larger questions of unequal power relations. Vi makes it quite clear that Columbus's false claim of 'discovery' and the resulting European colonial claiming of the Americas would be completely reconfigured according her notion of justice. Vi's emotive response and insistence on social justice hinges on her stance of equalizing power relations between the two opposing groups.

Julia proceeded to move the question for response from, 'How would you feel?' to 'What would you do?' Her students were then invited to imagine what they might have changed about the first encounter if they had been there. Students creatively acted upon their vision of a more socially just view of the contact zone through narrative drama, role playing, and improvisation. For instance, rather than leading the settlement of a prospective colonial nation, Julia's students role-played a defeated Columbus who found he was forced to leave North America peacefully simply because he couldn't understand the language of communication upon first contact.

Julia's approach to teaching Littlechild's text allowed for an enriched flexibility toward aesthetic and efferent experiences with texts, as Yenika-Agbaw (1997, p. 447) has urged educators toward developing in the curriculum. Yenika-Agbaw suggests "efferent and aesthetic readings must be reinforced with readings that propagate social change- readings that enable readers to ask questions, about situations and ideas they encounter within texts" (p. 447). She argues that postcolonial and critical multicultural readings of children's literature "will increase [children's] awareness of their society as they strive to participate in its democracy" (p. 453). Similarly through their critical engagement with texts, students in Julia's class were imagining and acting upon alternative democratic possibilities in their rethinking of historical injustices.

Julia brings her self-identity as a social critic who values democratic, critical mulitcultural, antiracist processes in learning into her work as a curriculum planner and educator. Her critical readings of mandated curriculum counter the regulation of knowledge as dictated by curriculum reform movements. Curriculum theorists have written extensively about the move toward regulated knowledge through prescribed curriculum (Apple, 1993). The Ontario social studies curriculum can be seen as a limited, regulated, or prescriptive document because it succeeds in shaping teacher thinking toward specific limited ways of conceptualizing curriculum and pedagogy. It purposefully regulates, dictates, and sets limits on knowledge areas that are expected to be covered by teachers in turn teachers are not required or expected to go beyond the goals outlined unless there is a vision or political commitment or interest in doing so.

Studying the subjectivity, political commitments, and practices of transformative educators such as Julia Neuman in this section and Sita Ramana in the next section, demonstrate there remains spaces for the assertion of teachers beliefs about equity and antiracist approaches in teaching which work 'against the grain' of conservatism and the regulation of the curriculum.

\section{An Inside Look into Sita's Classroom and Multilingual Equity Teaching Stances}

Teachers' ideological beliefs in equity empower them to negotiate with the expectations of the school and mandated curriculum. Sita Ramana's beliefs and political commitments in teaching are focused

Brock Education, 21(1), 33-52 
on the notion that excellence as well as equity should be integrated into learning. Sita's approach supports many of the beliefs espoused by transformative multiculturalists. According to Banks (1993), transformative multicultural education operates in conjunction with four components: equity pedagogy, content integration, knowledge construction and an empowering school culture.

Sita's beliefs in excellence as well as equity converge with Banks' (1993) notion of 'equity pedagogy.' According to Banks, "equity pedagogy exists when teachers modify their teaching in ways that facilitate the academic achievement of students from diverse racial, cultural, gender, and socialclass groups" (p. 23). Similarly Sita's beliefs in supporting multilingual communication patterns in her classroom converge with literacy theorists such as Cummins (1996), Luke and Freebody (1997), Powell (1999) and culturally responsive teaching as Gay (2000) describes it. These theories coincide with and support Banks' concern with content integration and the knowledge construction process. Culturally responsive teachers like Sita integrate curriculum content that is relevant to the cultural identities and lives of their students (in this case, the majority of students were South Asian). Further the knowledge construction process invites students to participate in the kind of critical dialogue that assists them toward critiquing knowledge production in social science and other subject areas (with the view to assert their own marginalized cultural histories).

Sita noted that when she first began teaching at Elmwood, there was an understanding of the need to promote excellence however there remained a gap in the area of equity. Recognizing this gap in the curriculum of the school, she decided to "specifically respond to the diversity of Elmwood." Sita explains:

There was a lot of attention in the area of enhancing student achievement [but] that [equity] would enhance their achievement as well...I thought I could start off by recognizing their experiences and their viewpoints and the two or three social groups which seemed to be outside [of the curriculum]. Even if we had a lot of South Asian students particularly Punjabi...their viewpoint was not included. So I felt that needed to be included since I wanted to provide an inclusive curriculum [Sita, teacher librarian].

Sita expressed her concerns and commitment toward legitimizing South Asian students' silenced and excluded voices within the curriculum knowledge of the school. To infuse the curriculum with a knowledge basis that represented the community of learners at Elmwood, Sita reflected on ways to reshape the "official expectations of the school." For instance from 1997 to 2000 the school improvement initiatives were literacy based, the focus being on oral and written language development. In the role of teacher librarian, Sita used partnered time (in which she would teach a given class in the library) to construct a culturally responsive curriculum alongside other critical minded educators.

\section{Sita's Transformative Work in Elmwood School: Changing Teacher Practice}

Sita worked toward an "empowering school culture" (Banks, 1993, p. 22), one that validated and affirmed the cultures of South Asian students. She began the school year by extending an invitation to teachers to partner with her in developing curriculum units using both her assistance (as the teacher

Brock Education, 21(1), 33-52 
librarian) and the resources that she brought into the school library. These resources included dual language books and multicultural, multiethnic children's literature. Sita attended all grade level meetings to invite teachers to become co-curriculum developers of culturally responsive, theme-based units. Working in this capacity with interested teachers, Sita assisted them to develop programs in language arts, social studies, science, and math.

In her own practice, Sita recognized that what created profound learning moments for South Asian students were academic components of a literacy-based school vision that worked in conjunction with culturally responsive teaching to create an equity curriculum. Sita reflected on the affective domain and the impact of using children's books with South Asian themes in relation to the learners' level of interest and participation in classroom learning. She explains:

I used a lot of [South Asian] stories, myths and legends and the kids themselves, the moment I started speaking to them, it empowered them to say their viewpoint. They would start bringing in pictures of their trips home to India, they would start bringing in their indigenous instruments...Then there was hours of sharing. (Sita, teacher librarian)

In her role as school librarian (and partner teacher), Sita worked toward creating meaningful classroom experiences in which students in her classroom (and other partnered teachers' classrooms) could express their home culture through a meaningful and culturally responsive curriculum. Sita achieved these transformative ends by fostering a collaborative working environment between herself and similar critical-minded teachers in her school. Sita worked with a core group of teachers at the school on initiating these programs. Figure 4 outlines the culturally responsive curriculum programs, transformative teaching practice, and collaborative partnerships that Sita initiated in the school. All these successes contributed toward an empowering school culture that was enriched by multicultural and culturally responsive curriculum development.

Sita made suggestions on developing multiple perspective approaches to developing units in social studies and language arts. For example Sita facilitated primary teachers toward thinking about integrating books like 'The Polar Bear Son' (Dabcovich, 1997) an Inuit tale about respect for nature, to a unit on Canada. She introduced 'Yeh-shen,' (Ai-Ling, 1982) a Cinderella story from China, to be used with other multicultural Cinderella stories. Her ongoing bibliography of available multicultural books and suggestions helped teachers to make shifts in their thinking and planning.

To accommodate Punjabi speaking children, Sita encouraged teachers to begin utilizing dual language books, an approach to teaching literacy that was novel to the teachers. To aid teachers' transition to selecting dual language books, Sita sent a special note to teachers "to contact your friendly teacher librarian for volunteer grandparents who are available to read in Punjabi and make an audio recording for the classroom." Grandparents would read the Punjabi side of the dual books alongside teachers during read aloud time as well as with individual children during D.E.A.R. time. Sita suggested that 'Raja's Big Ears' (Desaij, 1989) a dual Punjabi/English book might be compared with other tales such as 'Mitthu the Parrot' (Stone, 1989) providing time to discuss other languages and words (other than the dominant English language of instruction). Sita's initiatives created new contexts for the inclusion of students' language in the curriculum of the classroom. 
Figure 4: Components of Sita's Transformative Work in the School

\begin{tabular}{llll}
\hline Culturally Responsive & Context & Inspiring Practice Based & School Culture \\
Pedagogy and Curriculum & & on Commitments to \\
& Transformative Pedagogy & \\
& &
\end{tabular}

\begin{tabular}{|c|c|c|c|}
\hline $\begin{array}{l}\text { Multicultural books e.g. } \\
\text { folktales, legends, and } \\
\text { realistic fiction } \\
\text { (multicultural book talks / } \\
\text { workshops on how to } \\
\text { implement multicultural } \\
\text { texts in classrooms). }\end{array}$ & $\begin{array}{l}\text { Inservice staff } \\
\text { development for } \\
\text { partnered teachers }\end{array}$ & $\begin{array}{l}\text { Established equity } \\
\text { approaches to teaching } \\
\text { by including the cultures } \\
\text { of the classroom in } \\
\text { reading materials. }\end{array}$ & $\begin{array}{l}\text { Collaborative collegial } \\
\text { environment supported co- } \\
\text { learning and cultural border } \\
\text { crossing. }\end{array}$ \\
\hline $\begin{array}{l}\text { Dual language books e.g. } \\
\text { Punjabi/English used in } \\
\text { the curriculum. }\end{array}$ & $\begin{array}{l}\text { Partnered teaching } \\
\text { (collaboration between } \\
\text { critical minded } \\
\text { educators). }\end{array}$ & $\begin{array}{l}\text { Fostered the } \\
\text { development of a border } \\
\text { crossing teacher identity }\end{array}$ & $\begin{array}{l}\text { Teachers acquired knowledge } \\
\text { about the cultural and linguistic } \\
\text { backgrounds of their students. }\end{array}$ \\
\hline $\begin{array}{l}\text { All About Me Booklets in } \\
\text { the shape of a 'Deepa.' } \\
\text { Community school } \\
\text { bridges }\end{array}$ & $\begin{array}{l}\text { Partnered teaching } \\
\text { (collaboration between } \\
\text { educators). }\end{array}$ & $\begin{array}{l}\text { Belief that the } \\
\text { curriculum should } \\
\text { reflect excellence as } \\
\text { well as equity* }\end{array}$ & $\begin{array}{l}\text { Children's funds of knowledge } \\
\text { are actively legitimized in school } \\
\text { curriculum }\end{array}$ \\
\hline $\begin{array}{l}\text { Grandparents } \\
\text { read dual } \\
\text { language books } \\
\text { to children. }\end{array}$ & $\begin{array}{l}\text { Invited grandparents to } \\
\text { participate in literacy } \\
\text { programs. }\end{array}$ & $\begin{array}{l}* \text { e.g. In the area of oral } \\
\text { development, children } \\
\text { are invited to speak } \\
\text { about religious stories in } \\
\text { their own language }\end{array}$ & $\begin{array}{l}\text { Developing literacy in the child's } \\
\text { first language- making } \\
\text { connections between the child's } \\
\text { first language and English. }\end{array}$ \\
\hline $\begin{array}{l}\text { Members of the } \\
\text { community are } \\
\text { invited to teach } \\
\text { heritage language } \\
\text { classes. }\end{array}$ & $\begin{array}{l}\text { Supported the } \\
\text { initiation of after } \\
\text { school programs run } \\
\text { by family members of } \\
\text { the community. }\end{array}$ & & $\begin{array}{l}\text { Providing a context for children } \\
\text { to see their cultural and linguistic } \\
\text { identities affirmed in the } \\
\text { curriculum. }\end{array}$ \\
\hline
\end{tabular}

Sita acknowledged that the commitment of like-minded teachers was central to reshaping the curriculum. Each teacher seemed to be simultaneously positioned as expert and as learner in this mutually creative professional learning environment. Not only did Sita set out to support teachers in professional development through book talks on teaching South Asian folktales, legends, and dual language books, she also became an active learner as well. 


\section{'Making cultural bridges' in the curriculum an ongoing reality}

Sita acknowledged that her own beliefs were consolidated through her collaborative relations with other like-minded educators in her school, including the resource teacher. Recounting a series of ongoing strategies she used to bring about change in the school, Sita also mentioned that she contacted the school's resource teacher, Gloria Nicholson, to gain further innovative ideas for curriculum program development. Gloria enhanced Sita's own efforts in developing and teaching learning activities relating to the theme of celebrations. Sita explained:

I realized, Gloria really has the inside knowledge [of Indian culture] when she said to me, "If you really want to do more partnering [with teachers] then do this with the Grade 2s." She drew a lamp called a Deepa - [a clay lamp which is lit during Diwali], gave me her outline of the Deepa - and then suggested that I use the Deepa shape for an 'All about me' shaped booklet. So her idea was that you would talk about all the celebrations the children have, and all the stories that go with them and all the food that goes with it, at the Grade 2 level and compile them in the Deepa booklet. (Sita, teacher librarian)

Sita commented about this particular exchange between Gloria and herself. Sita said of Gloria (who is white): "She really has the inside knowledge." Sita's comment shows that other educators had similar interests in developing a culturally responsive curriculum. Further to that, it demonstrates a recognition that developing a culturally responsive curriculum is the responsibility of all educators who work in culturally diverse communities.

An ethic of caring which includes learning about the cultures that are represented in a school is central to developing a border crossing identity. Gloria actively applied both an inside knowledge and ethic of caring in creatively developing culturally responsive curriculum like the Deepa-shaped 'All About Me' booklet. Sita went on to explain how Gloria's inside knowledge as a cultural worker added to and extended her teaching in supporting ESL learners. For instance Sita capitalized on her own linguistic inside knowledge of the community by making the 'All About Me' Deepa-shaped booklet linguistically inclusive so that children felt invited to bring in their own language background during the activity.

\section{Learning through Culturally Responsive Practices}

Sita encouraged the children in her school, to draw from their primary discourse (or what they know) (Gee, 1992; Moll \& Gonzalez, 1997). She made the children feel comfortable making bridges between what they knew and literacy experiences in the classroom. In this way the curriculum provided opportunities for real and meaningful context from both cultural and linguistic perspectives. 
She supported the children in learning to think, reflect, and express their everyday life experiences in the context of the classroom. The curriculum validated the experiences they brought to school and was supported by critical minded educators who applied these to the learning contexts, as a 'legitimate knowledge basis in the classroom.' A culturally response curriculum and pedagogy opened up the separation between the school and home lives for children in the teacher librarian partnership classes in which Sita taught. Children saw and experienced their language and culture being validated in the classroom and utilized this understanding to share what they knew with Sita and each other. The classroom curriculum validated the child's sense of place, belonging, and community and gave active expression to the linguistic and cultural knowledge basis or cultural capital that the children represented. In this sense, children's funds of knowledge were legitimized.

Sita described the special importance of using the linguistic background of students to provide possibilities for them to become actively engaged in the learning in the classroom. She explained this commitment to bridging home and school cultures as follows:

When I looked into the faces of young children and knowing that I speak the same language which they do...I couldn't expect them to sit for 45 minutes and listen to me blabber in English knowing that they couldn't understand a word of it. So when I asked them something in their own language, say Tamil or Punjabi they would then come out [speaking] in that language. So I felt at least, somewhere I have to build their own language....I have to build that [opportunity] in so that child feels they are contributing.

(Sita, teacher librarian)

Sita encouraged Tamil and Punjabi speaking children to narrate religious stories in their own language. In this way, Sita facilitated building bridges between home and school cultures in even further ways in that the classroom environment invited not only culture and language but also religious faith so that children's cultural and linguistic multiple identities developed (Dyson, 1993, Schmidt, 1998).

\section{Bringing the community into the school}

Sita carried a sense of value for the linguistic backgrounds of the children of the school. Whether they were Punjabi, Tamil or Hindi speaking children, Sita worked toward the inclusion of what they knew into their everyday experiences of the classroom. She achieved this end in multiple ways: by assisting teachers to revise language instruction so that these became more culturally responsive, and by bringing significant members of the community into the school as resources to enrich children's learning during various literacy events.

\section{The special role of grandparents in children's learning}

Many components contributed to the creation of engaged learning moments for South Asian children,

Brock Education, 21(1), 33-52 
both in Sita's partnered curriculum, developed in collaboration with other teachers and in her own library/classroom. These contributed toward building links between home and school cultures. When Sita described the community of the classroom, the grandparent in the classroom is made note of in special ways because the grandparent enriches the sense of home, community, and belonging experienced in the classroom. Sita interpreted the grandparents' presence as playing a very important role in solidifying the connections between home and school culture. Their involvement was part of Sita's project of bringing the community into the school. She recognized that grandparents are central to the lives of children often playing the role of care giver when parents worked overtime, or double shifts (both night and day). Grandparents responded with their linguistic resources when teachers called upon them to read the Punjabi side of the dual language books or to listen to children's stories (written in Punjabi, Tamil, Sanskrit, Urdu). Grandparents were committed to ensuring language experiences in the children's first language or mother tongue were provided. As a person with a multilingual background, Sita recognized that Tamil and Hindi speaking children as well as other linguistic speakers needed to have opportunities to further develop knowledge of their mother tongue. To facilitate further first language learning opportunities Sita also coordinated the development of a heritage language program in the school. Sita's ethic of caring and sense of moral responsibility to children of multilingual South Asian backgrounds is reflected in her dedication to ensuring that these programs were created.

\section{Conclusion}

The work of critical educators like Sita and Julia needs to be contextualized in relation to reform movements in education which in the popularized bid to raise standards in education also involve the further subjugation of linguistic, social and cultural differences in the design of the curriculum, despite the fact of Ontario's racially and culturally diverse student population. Teachers like Sita use their insider knowledge as representatives of their communities to provide a transformative emancipatory/pedagogy. Similarly, Julia's critical reflection on how top down regulated curriculum can lead to exclusionary cultural practices in the curriculum contributes to her critique of the reimposing of a Eurocentric knowledge basis in the curriculum. Julia and Sita's teaching practices both demonstrate how teachers' utilize a cultural border crosser identity in order to reshape the curriculum so that it reflects the cultural backgrounds of their students. These teachers actively subvert the regulation of a culturally neutral curriculum and place social justice approaches at the center of their work with multiracial children.

Though mandated curriculum suggests that discourses of surveillance and the control of teachers' work are a given, teachers respond as intellectuals (Giroux, 1988), by critically questioning systems of control which threaten both their sense of professionalism and self control. As intellectuals teachers reflect critically on what they view as politically meaningful teaching practices and arise as authors (Casey, 1993) and agents of social change (Weiler, 1988). 


\section{References}

Apple, M. W. (1993). The politics of knowledge. London: Open University Press.

Banks, J. A. (1993). Approaches to multicultural curriculum reform. In Banks, J. A., \& McGee Banks, Eds., Multicultural education: Issues and perspectives, $2^{\text {nd }}$ Ed. (pp. 195-214) Boston: Allyn \& Bacon.

Casey, K. (1993). I answer with my life: life histories of women teachers working for social change. New York: Routledge.

Cummins, J. (1996). Negotiating identities: education for empowerment in a diverse society. Ontario, CA: California Association for Bilingual Education.

Dei, G. J. S. (1996). Anti-racism education: theory and practice. Halifax: Fernwood Publishing.

Dyson, A. Hass. (1993). Social worlds of children learning to write in an urban primary school. New York: Teachers College Press.

Frankenberg, R. (1997). White women, race matters: the social construction of whiteness. Minneapolis: University of Minnesota Press.

Gay, G. (2000). Culturally responsive teaching: theory, research, and practice. New York: Teachers College Press.

Gee, J. P. (1992). What is literacy? In P. Shannon (Ed.), Becoming political: readings and writings in the politics of literacy education (pp. 21-28). Portsmouth, NH: Heinemann.

Geiger, S. N. G. (1992). What's so feminist about doing women's oral history? In C. JonhsonOdim \& M. Strobel (Eds.), Expanding the boundaries of women's history (pp. 307-318). Bloomington: Indiana University Press.

Giroux, H. A. (1988). Teachers as intellectuals: a critical pedagogy for practical learning. South Hadley, MA: Bergin \& Garvey.

Glesne, C., \& Peshkin, A. (1992). Becoming qualitative researchers: an introduction. White Plains, NY: Longman.

Heron, L. (1985). Introduction. In L. Heron (Ed.), Truth, dare or promise: girls growing up in the fifties (pp. 1-9). London: Virago Press.

Brock Education, 21(1), 33-52 
Henry, A. (1998). Taking back control: African Canadian women teachers' lives and practices. Albany: State University of New York Press.

Leland, C. H. \& Harste, J. C. (1999). Is this appropriate for children?: gooks that bring realistic social issues into the classroom. Practically Primary, 4(3), 4-6.

Luke, A., \& Freebody, P. (1997). The social practices of reading. In S. Muspratt, A. Luke, \& P. Freebody (Eds.), Constructing critical literacies (pp. 185-225). Cresskill, NJ: Hampton.

Lund, D. E. (2003). Educating for social justice: Making sense of multicultural and antiracist theory and pracitice with Canadian teachers activists. Intercultural Education, 14(1), 3-16.

May, S. (1999). Critical multicultural work. Toronto: Multilingual Matters.

McLaren, P. (1994). Life in schools: An introduction to critical pedagogy in the foundations of education. Los Angeles: Longman.

Mogadime, D. (2003). Giving meaning to women teachers' life histories and political commitments in the classroom (Dissertation, University of Toronto).

Moll, L. \& Gonzalez, N. (1997). Teachers as social scientists: learning about culture from household research. In P. M. Hall (Ed.), Race, ethnicity, and multiculturalism (pp. 89114). New York: Garland.

Pearson, P. D., \& Raphael, T. E. (1998). Toward an ecologically balanced curriculum. In L. B. Gambrell, L. Mandel Morrow, S. B. Neuman \& M. Pressley (Eds.), Best practices in literacy instruction (pp. 22-33). New York: Guilford Press.

Portelli, J. P., \& Solomon, R. P. (2001). Introduction. In J. P. Portelli \& P. Solomon (Eds.), The Erosion of democracy in education from critique to possibilities, (pp. 15-27). Calgary: Detselig Enterprises.

Powell, R. (1999). Literacy as a moral imperative: Facing the challenge of a pluralistic society. New York: Rowman \& Littlefield.

Simon, R. (1992). Teaching against the grain: Texts for a pedagogy of possibility. Toronto: Ontario Institute for Studies in Education.

Schmidt P. Ruggiano (1998). Cultural conflict and struggle: literacy learning in a kindergarten program. New York: Peter Lang.

Brock Education, 21(1), 33-52 
Sleeter, C. E. (1994). White racism. Multicultural Education, 1(4), p.8

Sleeter, C. E. \& Delgado Bernal, D. (2004). Critical pedagogy, critical race theory and antiracist education. In Handbook of research on multicultural education $2^{\text {nd }}$ Ed., (pp. 240-258).

Weiler, K. (1988). Women teaching for change: gender, class and power. New York: Bergin \& Garvey.

Yenika-Agbaw, V. (1997). Taking children's literature seriously: reading for pleasure and social change. Language Arts, 74(7), 6 446-453.

\section{Children's Literature}

Ai-Ling, L. (1982).Yeh-Shen (4 ${ }^{\text {th }}$ ed.). New York: Philomel Books

Alki (1998). Marianthe’s story. New York: Green Willow Books.

Brenner, B. (1993). Wagon wheels. New York: Harper Collins.

Chin-Lee, C. (1982). A is for Asia. New York: Orchard Books.

Dabcovich, L. (1997). The polar bear son: an Inuit tale. New York: Houghton, Mufflin.

Demi (1997). One grain of rice: a mathematical folktale. New York: Scholastic, Press.

Desaij, N. (1989). The raja's big ears. London: Jennie Ingham Associates.

Fitch, Sheree (1997). If you could wear my sneakers. Toronto, Ontario: Doubleday.

Hill, L. (1993). Trails and triumphs: the story of African-Canadians. Toronto: Umbrella Press.

Littlechild, G. (1993). This land is my land. Emeryville, CA Children's Book Press.

Shemie, B. (1995). Houses of adobe: Native dwellings the southwest. New York: Tundra Books.

Stone, S. (1989). Mitthu the parrot. London: Ingham Publishers.

Tomas, J. C. (1996). I have heard of a land. New York: Harper Collins Publishers.

Waterton, B. (1980). Pettranella. Vancouver: Douglas \& McIntyre.

Yee, P. (1996a). Ghost train. Toronto, ON: Umbrella Press.

Yee, P. (1996b). Struggle and hope: The story of Chinese Canadians. Toronto: Umbrella Press. 